\title{
Viscosity of plasma in patients with rheumatoid arthritis
}

\author{
METTE HARREBY, BENTE DANNESKIOLD-SAMS $\varnothing E$, JACOB KJER, \\ AND MOGENS LAURITZEN \\ From the Department of Rheumatology and Clinical Chemistry, Kommunehospitalet, Copenhagen, Denmark
}

SUMMARY The viscosity of plasma (PV) was investigated in 27 outpatients with classical or definite rheumatoid arthritis (RA) according to the American Rheumatism Association (ARA) criteria. The measurements showed a significantly raised PV in patients with $\mathrm{RA}\left(\mathrm{p}<10^{-5}\right)$ compared with a control group. There was a positive correlation between the PV and the blood erythrocyte sedimentation rate (B-ESR), and the increase in the PV is largely explained by increased concentrations of the plasma proteins, fibrinogen, and IgG.

Key words: B-ESR, fibrinogen, IgG, blood sedimentation.

It is well established that the PV and the B-ESR increase in RA, ${ }^{1-3}$ and it has been shown that the $\mathrm{PV}$ is affected mainly by the plasma proteins, fibrinogen, and gammaglobulin. ${ }^{46}$

We have investigated the relationship between PV, B-ESR, and the concentrations of plasma proteins likely to affect viscosity both in patients with RA and healthy subjects.

\section{Patients and methods}

PATIENTS

Twenty seven outpatients, 17 female and 10 male, mean age 63 (SD 10) years, with classical or definite RA according to the ARA criteria were investigated. All were receiving aurothiomalate or penicillamine and/or non-steroidal anti-inflammatory drugs; none had received corticosteroids during the previous six months. Twenty five healthy subjects, 15 female and 10 male (aged 39 (10) years), were used as a control group.

Blood specimens were taken by venepuncture in the morning after eight hours of fasting. Ethylenediaminetetra-acetate (K $\mathrm{K}_{2}$ EDTA $4.0 \mathrm{mmol} / \mathrm{l}$ blood) was used as anticoagulant, and plasma was separated from the blood cells by centrifugation within one hour of venepuncture.

MEASUREMENTS

The erythrocyte sedimentation rate (B-ESR) was

Accepted for publication 23 March 1987.

Correspondence to Dr Mette Harreby, Toclloesevej 64, DK-4330 Hvalsoe, Denmark. measured by the methods of Westergren (1926) and performed within one hour of venepuncture.

The viscosity of the plasma (PV) was measured using a Wells-Brookfield microviscometer, model LVT cone/plate ${ }^{7}$ at $37 \cdot 0^{\circ} \mathrm{C}$ and a shear rate of 230

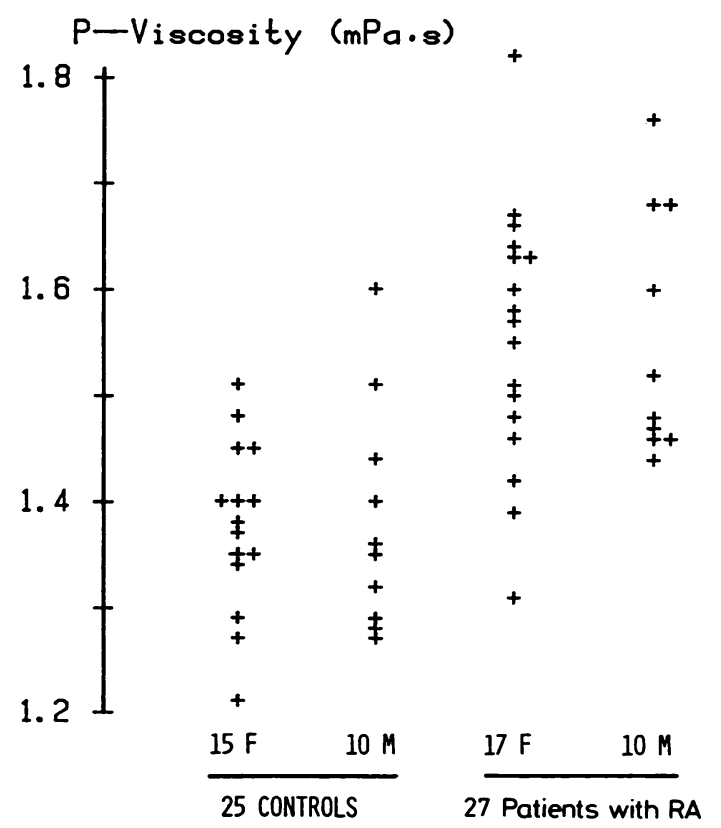

Fig. 1 Viscosity of plasma measured at $37^{\circ} \mathrm{C}$. Twenty five healthy subjects (15 female, 10 male) and 27 patients with rheumatoid arthritis (17 female, 10 male). 
$\mathrm{s}^{-1}$. The volume of the specimen in the cup was $1 \cdot 1$ $\mathrm{ml} .^{8}$ Measurements were performed within four hours of venepuncture. All results are mean values from duplicate measurements.

Plasma concentrations were determined as follows: (a) albumin (P-albumin) by an endpoint turbidometric assay using antibodies against humarew albumin; (b) fibrinogen (P-fibrinogen) by a kinetie turbidometric assay using antibodies against humars fibrinogen; (c) fibronectin (P-fibronectin) by nephelometric assay using antibodies against fib흘 ronectin; (d) immunoglobulins (P-IgG, P-IgA, $\mathrm{P} \frac{\bar{D}}{\vec{D}}$

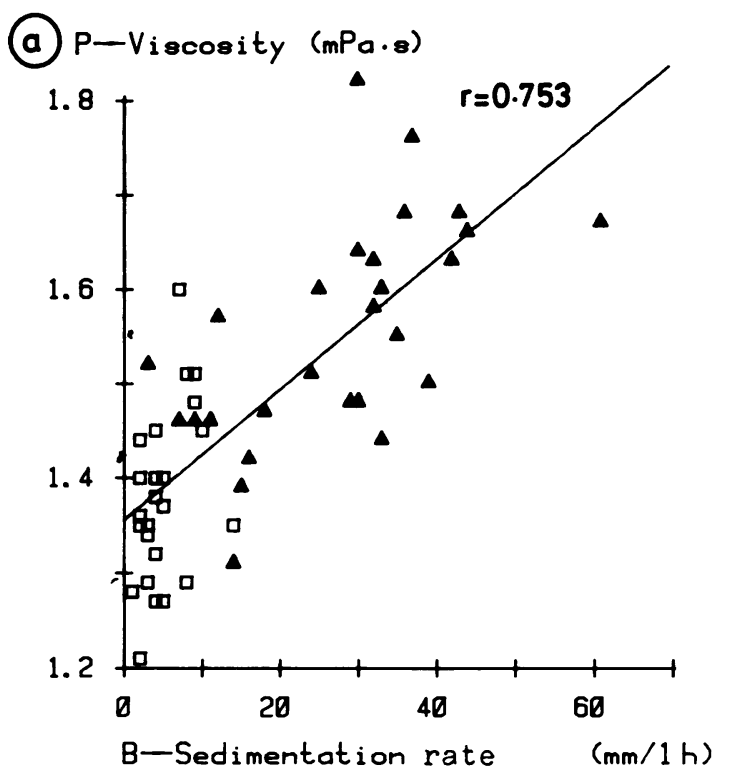

(b) $\mathrm{P}-\mathrm{V}_{\text {iscosity }}(\mathrm{mPa} \cdot \mathrm{s})$

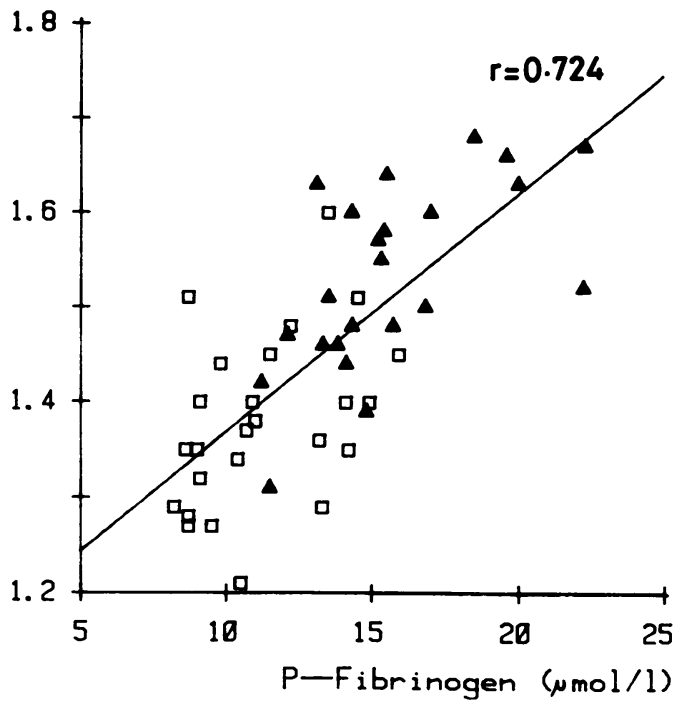

Controls

Patients with RA

(C) $\mathrm{P}-\mathrm{Viscosity}(\mathrm{mPa} \cdot \mathrm{s})$

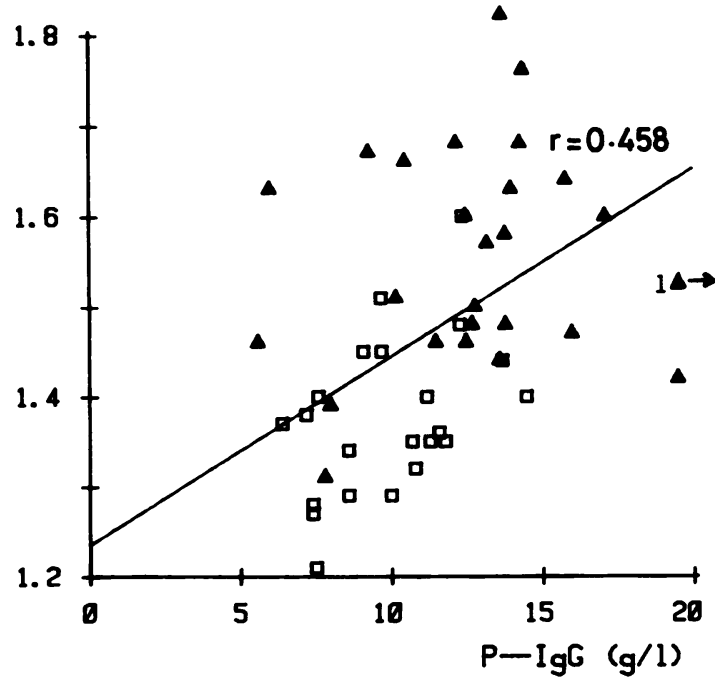

(d) $\mathrm{P}-\mathrm{V}_{\text {i scosity }(\mathrm{mPa} \cdot \mathbf{s})}$

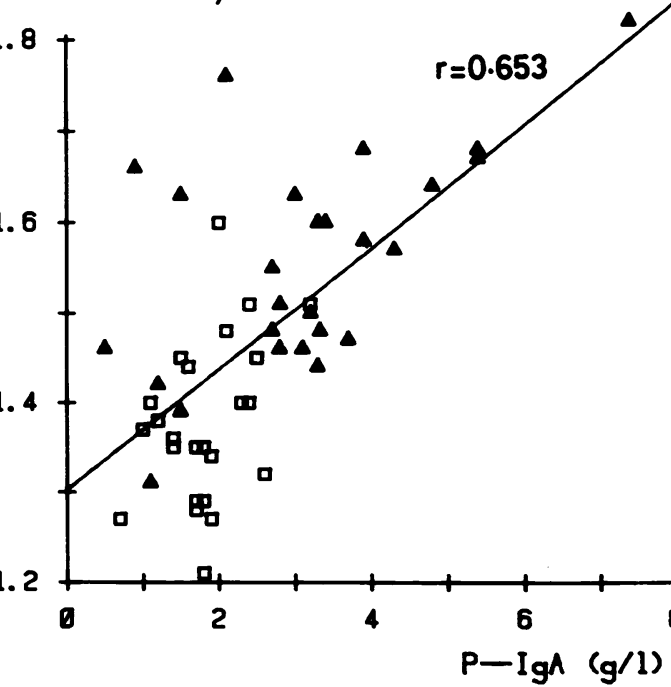

Fig. 2 Correlation between four different quantities $(a, b, c, d)$ measured in blood or plasma and the viscosity o\$ plasma measured at $37^{\circ} \mathrm{C}$. $\square=$ healthy controls; $\Delta=$ patients with rheumatoid arthritis; $r$ is the coefficient of correlation? 
Table 1 Comparison of quantities measured in blood, plasma, or serum from 25 healthy subjects and 27 patients with rheumatoid arthritis*

\begin{tabular}{|c|c|c|c|c|}
\hline $\begin{array}{l}\text { System }{ }^{+} \text {and } \\
\text { component }\end{array}$ & Unit & $\begin{array}{l}\text { Controls } \\
(n=25)\end{array}$ & $\begin{array}{l}\text { Patients with } R A \\
(n=27)\end{array}$ & $\begin{array}{l}U \text { test } \\
\text { ( } p \text { value })\end{array}$ \\
\hline P-viscosity & $\mathrm{mPa} . \mathrm{s}$ & $1.38(0.09)$ & $1.55(0.12)$ & $<10^{-5}$ \\
\hline B-ESR & $\mathrm{mm} / \mathrm{l} \mathrm{h}$ & $5 \cdot 0(3 \cdot 2)$ & $27.4(13.5)$ & $<10^{-5}$ \\
\hline P-albumin & $\mu \mathrm{mol} / \mathrm{l}$ & $581(40)$ & $501(51)$ & $<10^{-5}$ \\
\hline P-fibrinogen & $\mu \mathrm{mol} / \mathrm{l}$ & $11.2(2.4)$ & $15 \cdot 6(3 \cdot 1)$ & $<10^{-5}$ \\
\hline P-IgG & $\mathrm{g} / \mathrm{l}$ & $9.9(2 \cdot 2)$ & $13 \cdot 2(5 \cdot 1)$ & $<10^{5}$ \\
\hline P-IgA & $\mathrm{g} / \mathrm{l}$ & $1.8(0 \cdot 6)$ & $3 \cdot 1(1 \cdot 6)$ & $<10^{-5}$ \\
\hline P-IgM & $\mathrm{g} / 1$ & $1.5(0.7)$ & $1.4(1.0)$ & NS \\
\hline P-plasminogen & $\mu \mathrm{mol} / \mathrm{l}$ & $1.6(0 \cdot 3)$ & $1 \cdot 8(0 \cdot 3)$ & NS \\
\hline P-fibronectin & $\mu \mathrm{mol} / \mathrm{l}$ & $1.1(0.4)$ & $1.2(0 \cdot 2)$ & NS \\
\hline S-ferritin & $\mu \mathrm{g} / \mathrm{l}$ & $47(53)$ & $42(47)$ & NS \\
\hline P-antithrombin III & Arb. unit & $1 \cdot 1(0 \cdot 2)$ & $1 \cdot 2(0.2)$ & NS \\
\hline
\end{tabular}

${ }^{*}$ Levels are given as mean (standard deviation) and are tested for differences by the Mann-Whitney $U$ test. Two tailed probabilities are shown.

†B=blood: $\mathrm{P}=$ plasma: $\mathrm{S}=$ serum.

IgM), and plasminogen (P-plasminogen) by quantitative immunoelectrophoresis; and (e) antithrombin III (P-antithrombin III) by Coatest (Kabi, USA).

Ferritin (S-ferritin) was determined by the radioimmunosorbent assay, Prist (Pharmacia AB, Sweden).

\section{A N A L Y I IS}

Stepwise multiple linear regression analysis" was performed on data from the combined groups of individuals $(n=52)$. The dependent variable, $P V$, was expressed as a linear function of the independent variables, P-albumin, P-fibrinogen, P-IgG, PIgA, and P-IgM. The protein concentrations were all greater than $1 \mathrm{~g} / \mathrm{l}$.

\section{Results}

The results of the PV measurements are shown in Fig. 1. PV is independent of sex in both groups. In Table 1 the means and standard deviation of the measured quantities are given for controls and patients with RA. PV, B-ESR, P-fibrinogen, P-IgG, and $\mathrm{P}-\operatorname{IgA}$ were higher in patients with $\mathrm{RA}$ than in the controls $(p<0.001)$. PV is presented graphically against each of the above parameters (Figs 2a-2d). The corresponding simple correlations were all significant. P-albumin was lower in the patients with RA than in the controls. The influence of the individual plasma protein concentrations on PV was found by stepwise multiple linear regression analysis. Of the five different protein concentrations investigated simultaneously, P-fibrinogen was the best predictor of PV, followed by P-IgG and P-IgM. These three variables all contributed independently of each other to the PV variation $(\mathrm{p}<0.05$ by $t$ test $)$, whereas P-albumin and P-IgA did not. Fifty seven per cent of the total variation of PV was explained by P-fibrinogen alone. The fraction increased to $69 \%$ and further to $72 \%$ by the stepwise inclusion of $\mathrm{P}-\mathrm{IgG}$ and $\mathrm{P}-\mathrm{IgM}$ in the analysis. P-albumin and P$\operatorname{IgA}$ were not included. The residual unexplained $28 \%$ of total variation of PV corresponds to $0 \cdot 07$ $\mathrm{mPa} . \mathrm{s}$ when expressed as the standard error of estimate. The analytical error (repeatability) of the PV results was estimated by replicate measurements to $0.045 \mathrm{mPa} . \mathrm{s}(\mathrm{SD})$.

\section{Discussion}

Our results are in agreement with earlier investigations in finding a significant rise in PV and a correlation between PV and B-ESR. ${ }^{4}$ PV appeared to be a more sensitive test than B-ESR as the PV was abnormal earlier in the disease, ${ }^{10}$ but we find that the patients with RA are better distinguished from the controls by B-ESR than by PV (Fig. 2a). One explanation might be the greater experimental error shown by a cone/plate viscometer in our measuring conditions: $3 \%$ (coefficient of variation) compared with $0.5 \%$ by the capillary viscometer. ${ }^{10}$ "1 Higher relative values of B-ESR and PV for the patients with RA than for the controls ${ }^{11}$ may also lead to a different degree of separation. PV in the combined group of controls and patients with RA is mainly determined by P-fibrinogen. The second most important protein concentration is $\mathrm{P}$ IgG. The effect of P-IgM is just measurable. The much lower $\mathrm{P}$-albumin and the higher $\mathrm{P}-\operatorname{IgA}$ in patients with RA did not affect PV. P-plasminogen, P-fibronectin, S-ferritin, and P-antithrombin III were unchanged in RA. We do not expect these 
proteins to influence PV because of their low mass concentrations, less than $1 \mathrm{~g} / \mathrm{l}$. The diagnostic value of P-fibrinogen, $\mathrm{P}-\mathrm{IgG}$, and $\mathrm{P}-\mathrm{IgA}$ in $\mathrm{RA}$ seems comparable with that of $\mathrm{PV}$ or B-ESR.

Smoking, defined as smoking at least five cigarettes a day in the previous three months, is known to increase viscosity. ${ }^{12}$ In our control group 13 persons were smokers and eight non-smokers, but we found no significant difference in PV between these two groups. On the other hand, Pantithrombin III was significantly higher in smokers than in non-smokers. This observation deserves further investigation.

\section{References}

1 Cowan I C. Harkness J. The plasma viscosity in rheumatic diseases. $\mathrm{Br}$ Med J 1947; ii: 686-8.

2 T'ang $\mathrm{H} \mathrm{Y}$, Wang $\mathrm{S} \mathrm{H}$. The clinical application of plasma viscosity determination. Chinese Med $J$ 1940; 57: 546-55.

3 Houston J. Whittington R B. Cowan I C. Harkness J. The plasma-viscosity in pulmonary tuberculosis and rheumatic diseases. J Clin Invest 1949; 28: 752-63.
4 Crockson R A, Crockson A P. Relationship of erythrocyte sedimentation rate to viscosity and plasma proteins in rheuma-toid arthritis. Ann Rheum Dis 1974; 33: 53-6.

5 Hutchinson R M. Eastham R D. A comparison of erythrocytc $\stackrel{\vec{S}}{\stackrel{S}{+}}$ sedimentation rate and plasma viscosity in detecting changes in plasma-proteins. J Clin Pathol 1977; 30: 345-9.

6 Shearn M A. Epstein W. Engleman E P. Taylor W F $\bar{\omega}$ Relationship of serum proteins and rheumatoid factor to serum? viscosity in rheumatic diseases. J Lab Clin Med 1963; 61 : $677-86$.

7 Roe E. Wells R. Measurement of viscosity of biologic fluids by cone plate viscometer. J Lab Clin Med 1961; 57: 646.

8 Lauritzen M. Dybkaer R. Cone/plate viscosimeter and sub- specimen volume. Scand J Clin Lab Invest 1974; 33: 187-90. $\vec{\omega}$

9 Draper N R, Smith H. Applied regression analyses. Chichester:O Wiley 1966

10 Pickup M E, Dixon J S, Hallett C. Bird H A, Wright V. Plasma viscosity-a new appraisal of its use as an index of disease $\vec{D}$ activity in rheumatoid arthritis. Ann Rheum Dis 1981; 40" 272-5.

11 Harkness J. The viscosity of human blood plasma, its measurements in health and disease. Biorheology 1971; 8: 171-93.

12 Lowe G D O, Drummond M M, Forbes C D, Barbenel J C. The effects of age and cigarette-smoking on blood and plasmaviscosity in men. Scott Med J 1980; 25: 13-17. 